\title{
RESP18, a homolog of the luminal domain IA-2, is found in dense core vesicles in pancreatic islet cells and is induced by high glucose
}

\author{
Guofeng Zhang ${ }^{1, *}$, Hiroki Hirai*, Tao Cai, Junnosuke Miura, Ping Yu ${ }^{2}$, Hanxia Huang, Martin R Schiller ${ }^{3}$, \\ William D Swaim ${ }^{4}$, Richard D Leapman ${ }^{1}$ and Abner L Notkins \\ Experimental Medicine Section, Oral Infection and Immunity Branch (OIIB), National Institute of Dental and Craniofacial Research (NIDCR), The National \\ Institutes of Health (NIH), Bethesda, Maryland 20892, USA \\ ${ }^{1}$ Laboratory of Bioengineering and Physical Science, National Institute of Biomedical Imaging and Bioengineering, NIH, Bethesda, Maryland 20892, USA \\ ${ }^{2}$ Structure Biophysics Laboratory, National Cancer Institute at Frederick, Frederick, Maryland 21702, USA \\ ${ }^{3}$ Department of Molecular, Microbial and Structural Biology, University of Connecticut Health Center, Farmington, Connecticut 06030, USA \\ ${ }^{4}$ Therapeutics Branch of NIDCR, NIH, Bethesda, Maryland 20892, USA \\ (Correspondence should be addressed to T Cai; Email: tcai@mail.nih.gov) \\ *(G Zhang and $\mathrm{H}$ Hirai contributed equally to this work)
}

\begin{abstract}
The regulated endocrine-specific protein, RESP18, first found in the rat pituitary, was thought to be regulated by dopaminergic drugs. Bioinformatics studies showed that RESP18 shares sequence homology with the luminal region of IA-2, a dense core vesicle (DCV) transmembrane protein involved in insulin secretion. The present study was initiated to examine the genomic structure and subcellular localization of RESP18 and the effect of glucose on its expression. Human RESP18 was isolated from a pancreas cDNA library and its subcellular localization was determined by immunoelectron microscopy. MIN6 cells and mouse islets were used to study the effect of glucose on RESP18
\end{abstract}

expression. Bioinformatics analysis revealed that RESP18 and IA-2 are tandemly arranged within a $45 \mathrm{~kb}$ region on human chromosome 2 and share common intron-exon boundaries. By confocal microscopy, RESP18 was found in $\alpha, \beta$ and $\delta$ cells in the pancreatic islets. Electron microscopy revealed that RESP18 is present in the lumen of DCVs. The expression of RESP18 in $\beta$ cells is markedly increased following exposure to high glucose and also elevated in the islets of diabetic, but not non-diabetic, NOD mice. We conclude that RESP18 is a luminal protein of DCVs and its expression is regulated by exposure to glucose.

Journal of Endocrinology (2007) 195, 313-321

\section{Introduction}

IA-2 is a major autoantigen in type 1 diabetes and autoantibodies to it are widely used to identify subjects at high risk of developing type 1 diabetes for entry into therapeutic intervention trials (Lan et al. 1996). IA-2 is a member of the transmembrane protein tyrosine phosphatase (PTP) family (Lan et al. 1994, Lu et al. 1996, Wasmeier \& Hutton 1996, Cai et al. 2001a, Notkins 2002) and is found in dense core vesicles (DCVs) of many neuroendocrine tissues including the brain and pancreatic islets of Langerhans (Wasmeier \& Hutton 1996, Hermel et al. 1999). The IA-2 protein is 979 amino acids (aa) in length and consists of a luminal domain (aa 1-576), transmembrane domain (aa 577-599), and cytoplasmic domain (aa 600-979). Although a member of the PTP family, IA-2 lacks phosphatase activity with known substrates due to amino acid substitutions at critical sites in its PTP domain (Magistrelli et al. 1996). The IA-2 paralog, IA-2 $\beta$ (phogrin) is 76\% identical to the cytoplasmic domain of IA-2, but only $26 \%$ identical to the luminal domain of IA-2. Homologs of human IA-2 and IA-2 $\beta$ are found in species as distantly related as Drosophila and Caenorhabditis elegans (Cai et al. 2001a, 2004).
Bioinformatics has revealed that the first 200 amino acids of the luminal domain of IA-2 share significant homology with RESP18 (Schiller et al. 1997) that is found in the lumen of the endoplasmic reticulum (ER) of neuroendocrine cells (Schiller et al. 1995, Schiller \& Darlington 1996, Darlington et al. 1997a,b, Farkas et al. 2004). In the brain, RESP18 is thought to be regulated by dopaminergic drugs (Bloomquist et al. 1994a) with a half-life of $<20 \mathrm{~min}$. Very little is known, however, about this gene or the protein that it encodes. The present experiments were initiated to: 1) define the genomic structure of RESP18 and its relationship to IA-2;2) determine the cellular and subcellular localization of the RESP18 protein; and 3) evaluate its expression in $\beta$ cells in response to glucose.

\section{Materials and Methods}

Cloning of RESP18

The mouse RESP18 sequence was used to search human dbEST databases (http://www.ncbi.nlm.nih.gov), resulting 
in the identification of part of the human RESP18. Primers (forward, 5'-AGCCTGGGAG GATGCAGCAC-3'; reverse, $5^{\prime}$-ATCAGCCACAGGGTTGCGG-3') were designed to amplify full-length RESP18 from human pancreas cDNA libraries (BD Bioscience, Palo Alto, CA, USA). PCR products were cloned and sequenced as previously described (Cai et al. 2001b). Genomic structure of human RESP18 was determined by comparing the cDNA sequences of RESP18 isoforms and the genomic DNA sequence of RESP18 (GenBank accession no. AC114803.5).

\section{Northern blots}

Two micrograms poly-mRNAs of human multiple tissues northern blot were probed with ${ }^{32} \mathrm{P}$-labeled human RESP18 cDNA in ExpressHyb Hybridization Solution (BD Bioscience). After washing under high stringency conditions according to manufacturer's specifications, the blots were subjected to autoradiography at $-70{ }^{\circ} \mathrm{C}$.

\section{Real-time PCR}

Real-time PCR analysis was performed using RNA isolated from MIN6 cells (Qiagen RNeasy Mini kit). First-strand synthesis was carried out using the Brilliant Q-PCR RT-PCR kit (Stratagene, La Jolla, CA, USA) with $10 \mu \mathrm{g}$ isolated RNA that was treated with DNase I. Primers and probes of mouse RESP18 (Assay ID Details, Mm00485697_m1) and $\beta$-actin (Assay ID Details, Mm00607939_s1) were purchased from Applied Biosystems (Foster City, CA, USA). Real-time amplification of cDNAs was performed using the TaqMan Universal Master Mix and the primers in 9700HT real-time PCR Cycler (Applied Biosystems).

\section{Antibodies and western blots}

Peptide-specific polyclonal antibodies were raised in rabbits and purified as reported previously (Chen et al. 2001). Anti-rat RESP18 (JH1162) antibody was used as previously described (Bloomquist et al. 1994b). Anti-human RESP18 antibody (1/100 dilution), raised in rabbits and designated RESP18/SVL421, was made with amino acids 138-151 (CFTSEVVSKALKQE), which has no sequence commonality with IA-2, IA-2 $\beta$, or other human genes. Anti-insulin, anti-glucagon, and anti-somatostatin mouse monoclonal antibodies were obtained from Sigma. Western blots were performed using the Western-light Chemiluminescent Detection System (Tropix, Bedford, MA, USA). The software of NIH Image J was used to quantify the images (http://rsb.info.nih.gov/ij/)

\section{Immunofluorescence microscopy}

Paraffin embedded slides of human and rat pancreata were prepared and immunostaining was performed by standard methods. Microscopic analysis was done with a Zeiss Axiophot (Columbus, OH, USA) microscope equipped for immunofluorescence and with a Leica TCS 4D confocal laser scanning microscope (Leica Microsystems, Wetzlar, Germany).

\section{Pancreatic islet isolation}

Mouse and rat pancreatic islets were isolated by Liberase enzyme digestion according to a protocol provided by Roche Applied Science and by Ficoll density gradient purification (Sigma). All procedures were approved by the NIDCR Institutional Animal Care and Use Committee.

\section{Electron microscopy}

Rat pancreatic islets were isolated, fixed, and embedded by standard methods (Goping et al. 2003). Ultrathin sections $(\sim 80 \mathrm{~nm})$ were cut and placed on copper grids for viewing in a Philips CM120 transmission electron microscope (FEI, Hillsboro, OR, USA), operating at an accelerating voltage of $120 \mathrm{kV}$, and equipped with a GIF100 imaging filter (Gatan, Pleasanton, CA, USA). Zero energy-loss images were recorded digitally by means of a $1 \mathrm{k} \times 1 \mathrm{k}$ pixel cooled CCD camera using DigitalMicrograph software (Gatan). Immunolabeling of antigens was performed using immunogold. Briefly, the sections were exposed to blocking solution containing 2\% BSA, 2\% normal goat serum, and $0 \cdot 1 \%$ fish gelatin in PBS containing $0.05 \%$ Tween-20 (PBST) for $60 \mathrm{~min}$ and incubated with anti-RESP18/JH1162 polyclonal antibody $\left(1 / 20\right.$ dilution) overnight at $4{ }^{\circ} \mathrm{C}$, and then with an anti-insulin or anti-glucagon monoclonal antibody $(1 / 200$ dilution) for $2 \mathrm{~h}$ at room temperature or overnight at $4{ }^{\circ} \mathrm{C}$ for co-localization studies. The primary antibodies were detected with $5 \mathrm{~nm}$ diameter colloidal gold particles conjugated to goat-anti-rabbit IgG and $10 \mathrm{~nm}$ diameter colloidal gold particles conjugated to goat-anti-mouse IgG respectively (Ted Pella, Redding, CA, USA). The number of gold particles/ $\mu \mathrm{m}^{2}$ in DCVs and cytoplasm was counted as previously described (Murray \& Jin 1995).

\section{Glucose stimulation}

MIN6 cells were maintained as previously described (Miyazaki et al. 1990). Briefly, $1 \times 10^{6}$ cells were plated and grown for 2 days in six-well plates. On the third day, cells were rinsed in buffer A without glucose $(5 \mathrm{mM} \mathrm{KCl}, 120 \mathrm{mM}$ $\mathrm{NaCl}, 24 \mathrm{mM} \mathrm{NaHCO}, 1 \mathrm{mM} \mathrm{MgCl}, 2 \mathrm{mM} \mathrm{CaCl}$,

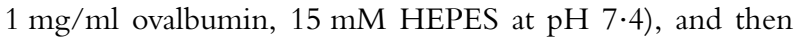
incubated in buffer A with $3.3 \mathrm{mM}$ glucose for $1 \mathrm{~h}$ to stabilize basal insulin secretion. After washing twice, cells were incubated for different times (15-180 min) in buffer A containing low glucose $(3.3 \mathrm{mM})$ or high glucose $(8.3 \mathrm{mM}$, $11 \cdot 1 \mathrm{mM}$ or $25 \mathrm{mM}$ glucose; Ort et al. 2001). 
A

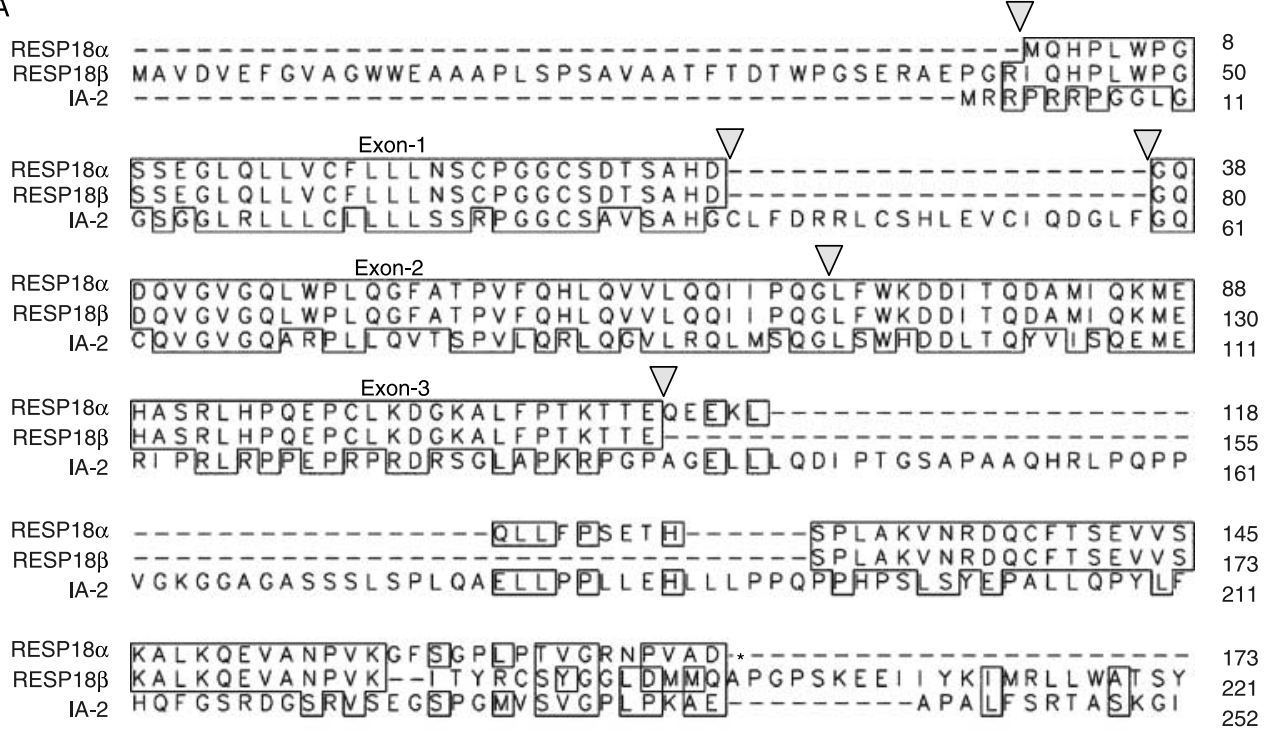

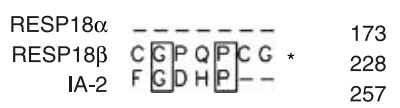

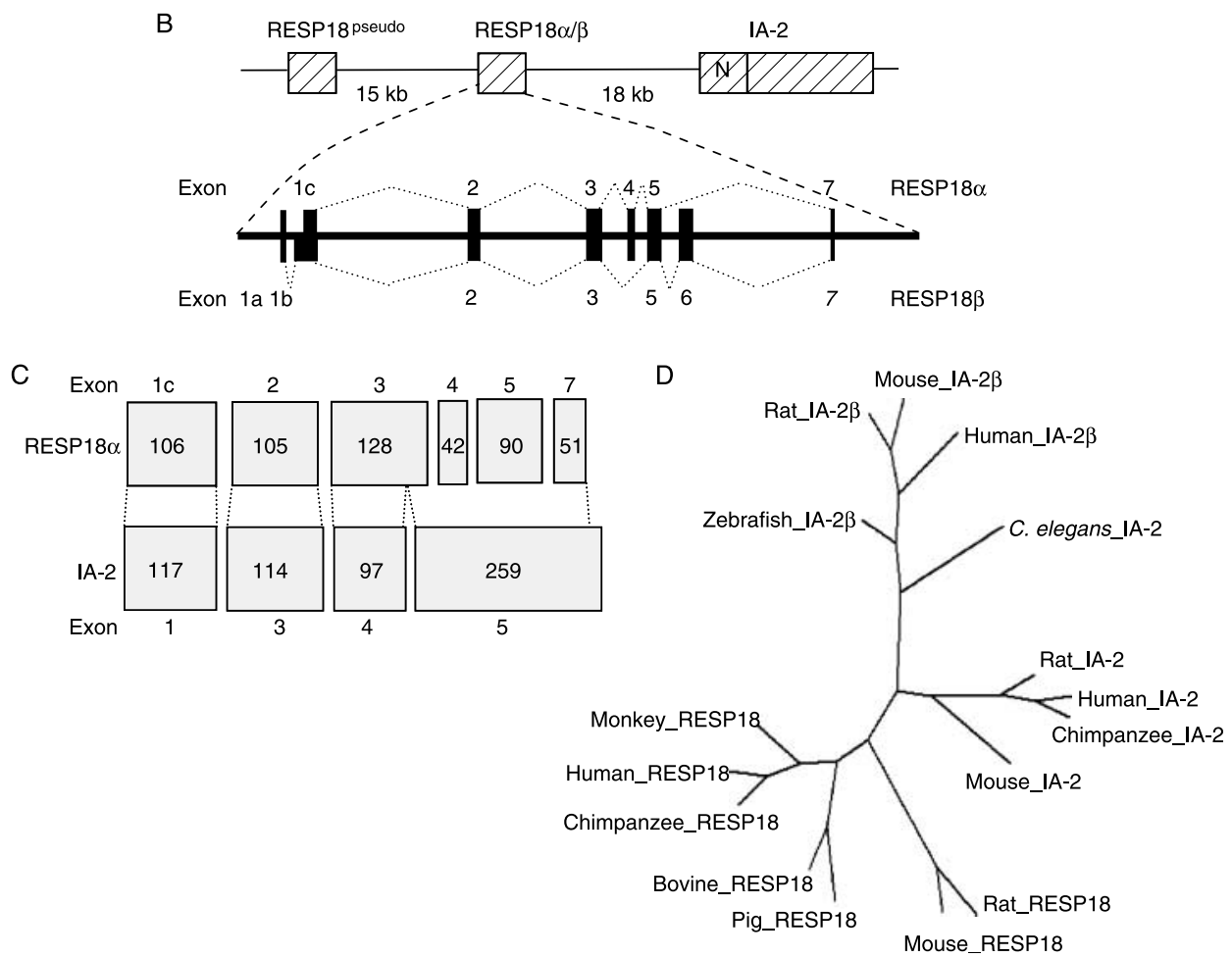

Exon $1 \mathrm{a} 1 \mathrm{~b}$

Figure 1 Sequence and genomic analysis of human RESP18. (A) Multiple sequence alignment of RESP18 $\alpha$, RESP18 $\beta$, and the N-terminal domain of IA-2. Similar and identical amino acids are boxed. The reversed triangles indicate common exon boundaries between RESP18 $\alpha$ and IA-2. (B) Genomic mapping of RESP18-pseudogene, RESP18 $\alpha / \beta$, and the N-terminal region of IA-2 on human chromosome $2 q 35$. Approximate position and relative size of exons (vertical bars) and introns (horizontal lines) of RESP18 $\alpha$ and RESP18 $\beta$ are indicated. (C) Schematic of the genomic organization of RESP1 $\alpha \alpha$ and the N-terminal region of IA-2. Each shaded box represents an exon and the number of nucleotides within each exon is indicated. (D) Computer generated phylogeny tree showing members of the IA-2 family. Length of each line represents relative relatedness. 
Table 1 Intron-exon junctions of human RESP18 genes

Sequence at intron-exon junction

\begin{tabular}{|c|c|c|c|c|c|c|c|c|c|c|c|c|}
\hline \multirow{3}{*}{$\begin{array}{l}\text { Exon } \\
\text { RESP18 }\end{array}$} & \multirow{2}{*}{$\begin{array}{l}\text { Size } \\
\text { (bp) } \\
\end{array}$} & \multirow[b]{2}{*}{ Intron } & \multirow{2}{*}{$\begin{array}{l}\text { Size } \\
\text { (bp) }\end{array}$} & & \multirow[b]{2}{*}{ Amino acids } \\
\hline & & & & \multicolumn{4}{|c|}{$5^{\prime}$-Splice donor } & \multicolumn{4}{|c|}{ 3'-Splice donor } & \\
\hline & & & & & & & & & & & & \\
\hline 1c & 106 & $1 b$ & 1647 & $\begin{array}{l}\text { GCC } \\
\text { A }\end{array}$ & $\begin{array}{l}\text { CAC } \\
\mathrm{H}\end{array}$ & $\begin{array}{l}\text { G } \\
\text { D }\end{array}$ & gtcagga...cccttag & AT & $\begin{array}{l}\text { GGT } \\
\text { G }\end{array}$ & $\begin{array}{l}\text { CAG } \\
\text { Q }\end{array}$ & $\begin{array}{l}\text { GAC } \\
\text { D }\end{array}$ & $1-36$ \\
\hline 2 & 105 & 2 & 1006 & $\begin{array}{l}\text { CCC } \\
\text { P }\end{array}$ & $\begin{array}{l}\text { CAA } \\
\text { Q }\end{array}$ & $\begin{array}{l}\mathrm{G} \\
\mathrm{G}\end{array}$ & gtaagta...cctgcag & GT & $\begin{array}{l}\text { CTG } \\
\text { L }\end{array}$ & $\begin{array}{l}\text { TTC } \\
\text { F }\end{array}$ & $\begin{array}{l}\text { TGG } \\
\text { W }\end{array}$ & $37-71$ \\
\hline 3 & 128 & 3 & 235 & $\begin{array}{l}\text { ACC } \\
T\end{array}$ & $\begin{array}{l}\text { ACT } \\
T\end{array}$ & $\begin{array}{l}\text { GAG } \\
\text { E }\end{array}$ & gtgaggt...ctcacag & $\begin{array}{l}\text { CAA } \\
\text { Q }\end{array}$ & $\begin{array}{l}\text { GAG } \\
\mathrm{E}\end{array}$ & $\begin{array}{l}\text { GAG } \\
\mathrm{E}\end{array}$ & & $72-113$ \\
\hline 4 & 42 & 4 & 110 & $\begin{array}{l}\text { GAG } \\
\mathrm{E}\end{array}$ & $\begin{array}{l}\text { ACT } \\
T\end{array}$ & $\begin{array}{l}\text { CAC } \\
\mathrm{H}\end{array}$ & gtatctt...ctctcag & $\begin{array}{l}\text { AGC } \\
S\end{array}$ & $\begin{array}{l}\text { CCC } \\
\mathrm{P}\end{array}$ & $\begin{array}{l}\text { CTG } \\
\text { L }\end{array}$ & & $114-127$ \\
\hline 5 & 90 & 5 & 1598 & $\begin{array}{l}\text { CCT } \\
\mathrm{P}\end{array}$ & $\begin{array}{l}\text { GTC } \\
\text { V }\end{array}$ & $\begin{array}{l}\text { AAG } \\
K\end{array}$ & gtgaggg...gttttag & $\begin{array}{l}\text { GGC } \\
\text { G }\end{array}$ & $\begin{array}{l}\text { TTC } \\
\mathrm{F}\end{array}$ & $\begin{array}{l}\text { TCT } \\
\text { S }\end{array}$ & & $128-157$ \\
\hline 7 & 51 & & & $\begin{array}{l}\text { TGT } \\
\text { C }\end{array}$ & $\begin{array}{l}\text { GGC } \\
\text { G }\end{array}$ & $\underset{\mathrm{b}}{\mathrm{TGA}}$ & $\ldots$ & & & & & $158-173$ \\
\hline \multicolumn{13}{|c|}{ RESP18 $\beta$} \\
\hline $1 \mathrm{a}$ & 17 & $1 \mathrm{a}$ & 422 & $\begin{array}{l}\text { GAT } \\
\text { D }\end{array}$ & $\begin{array}{l}\text { GTG } \\
V\end{array}$ & $\begin{array}{l}\text { GA } \\
\text { E }\end{array}$ & gtaaagt...taaacag & A & $\begin{array}{l}\text { TTC } \\
\mathrm{F}\end{array}$ & $\begin{array}{l}\text { GGA } \\
\text { G }\end{array}$ & $\begin{array}{l}\text { GTC } \\
\text { V }\end{array}$ & $1-6$ \\
\hline $1 b$ & 215 & $1 b$ & 1647 & $\begin{array}{l}\text { GCC } \\
\text { A }\end{array}$ & $\begin{array}{l}\text { CAC } \\
\mathrm{H}\end{array}$ & $\begin{array}{l}\text { G } \\
\text { D }\end{array}$ & gtcagga...cccttag & AT & $\begin{array}{l}\text { GGT } \\
\text { G }\end{array}$ & $\begin{array}{l}\text { CAG } \\
\text { Q }\end{array}$ & $\begin{array}{l}\text { GAC } \\
\text { D }\end{array}$ & $7-78$ \\
\hline 2 & 105 & 2 & 1006 & $\begin{array}{l}\text { CCC } \\
\text { P }\end{array}$ & $\begin{array}{l}\text { CAA } \\
\text { Q }\end{array}$ & $\begin{array}{l}\mathrm{G} \\
\mathrm{G}\end{array}$ & gtaagta....cctgcag & GT & $\begin{array}{l}\text { CTG } \\
\text { L }\end{array}$ & $\begin{array}{l}\text { TTC } \\
\text { F }\end{array}$ & $\begin{array}{l}\text { TGG } \\
\text { W }\end{array}$ & 79-113 \\
\hline 3 & 128 & 3 & 387 & $\begin{array}{l}\text { ACC } \\
T\end{array}$ & $\begin{array}{l}\text { ACT } \\
\mathrm{T}\end{array}$ & $\begin{array}{l}\text { GAG } \\
E\end{array}$ & gtgaggt...ctcacag & $\begin{array}{l}\text { AGC } \\
S\end{array}$ & $\begin{array}{l}\text { CCC } \\
\mathrm{P}\end{array}$ & $\begin{array}{l}\text { CTG } \\
\text { L }\end{array}$ & & 114-155 \\
\hline 5 & 90 & 5 & 154 & $\begin{array}{l}\text { CCT } \\
\text { P }\end{array}$ & $\begin{array}{l}\text { GTC } \\
\text { V }\end{array}$ & $\begin{array}{l}\text { AAG } \\
\mathrm{K}\end{array}$ & gtgaggg...ctctcag & $\begin{array}{l}\text { ATT } \\
\text { । }\end{array}$ & $\begin{array}{l}\text { ACC } \\
\text { T }\end{array}$ & $\begin{array}{l}\text { TAT } \\
Y\end{array}$ & & 156-185 \\
\hline 6 & 85 & 6 & 1359 & $\begin{array}{l}\text { ATC } \\
\text { । }\end{array}$ & $\begin{array}{l}\text { ATG } \\
M\end{array}$ & $\begin{array}{l}C \\
R\end{array}$ & gtaagta...gttttag & GG & $\begin{array}{l}\text { CTT } \\
\text { L }\end{array}$ & $\begin{array}{l}\text { CTC } \\
\text { L }\end{array}$ & $\begin{array}{l}\text { TGG } \\
\mathrm{W}\end{array}$ & 186-214 \\
\hline 7 & 47 & & & $\begin{array}{l}\text { TGT } \\
\mathrm{C}\end{array}$ & $\begin{array}{l}\text { GGC } \\
\text { G }\end{array}$ & $\begin{array}{c}\text { TGA } \\
{ }_{-}\end{array}$ & $\ldots$ & & & & & 215-228 \\
\hline \multicolumn{13}{|c|}{ RESP18-pseudo } \\
\hline 1 & 106 & 1 & 3766 & $\begin{array}{l}\text { GCC } \\
\text { A }\end{array}$ & $\begin{array}{l}\text { ATT } \\
\text { l }\end{array}$ & $\begin{array}{l}\mathrm{A} \\
\mathrm{K}\end{array}$ & gtcccca...cccttag & AG & $\begin{array}{l}\text { GGG } \\
\text { G }\end{array}$ & $\begin{array}{l}\text { CAG } \\
\text { Q }\end{array}$ & $\begin{array}{l}\text { ACC } \\
T\end{array}$ & $1-39$ \\
\hline 2 & 105 & 2 & 1381 & $\begin{array}{l}\text { CCT } \\
\mathrm{P}\end{array}$ & $\begin{array}{l}\text { CAA } \\
\text { Q }\end{array}$ & $\begin{array}{l}G \\
G\end{array}$ & gtgagac...tctgcag & GA & $\begin{array}{l}\text { TTG } \\
\text { L }\end{array}$ & $\begin{array}{l}\text { TTC } \\
\mathrm{F}\end{array}$ & $\begin{array}{l}\text { TGG } \\
\text { W }\end{array}$ & $1-51$ \\
\hline 3 & 133 & 3 & 239 & $\begin{array}{l}\text { GTC } \\
\mathrm{V}\end{array}$ & $\begin{array}{l}\text { ACC } \\
T\end{array}$ & $\begin{array}{l}\text { AGG } \\
\text { R }\end{array}$ & gtgaggt...tttctag & $\begin{array}{l}\text { GAG } \\
\mathrm{E}\end{array}$ & $\begin{array}{l}\text { CAA } \\
\mathrm{Q}\end{array}$ & $\begin{array}{l}\text { GCA } \\
\text { A }\end{array}$ & & $72-113$ \\
\hline 4 & 42 & 4 & 107 & $\begin{array}{l}\text { CTA } \\
\text { L }\end{array}$ & $\begin{array}{l}\text { AAG } \\
\mathrm{K}\end{array}$ & $\begin{array}{l}\text { TGA } \\
-{ }_{b}\end{array}$ & gtttccc...ccatcag & $\begin{array}{l}\text { AAC } \\
N\end{array}$ & $\begin{array}{l}\text { CCC } \\
\mathrm{P}\end{array}$ & $\begin{array}{l}\text { ATG } \\
M\end{array}$ & & 114-127 \\
\hline 5 & 102 & 5 & 2191 & $\begin{array}{l}\text { CTG } \\
\text { L }\end{array}$ & $\begin{array}{l}\text { CTC } \\
\text { L }\end{array}$ & $\begin{array}{l}\text { CAG } \\
\text { Q }\end{array}$ & gtaaggg...attttag & $\begin{array}{l}\text { GAC } \\
\text { D }\end{array}$ & $\begin{array}{l}\text { GTC } \\
\mathrm{V}\end{array}$ & $\begin{array}{l}\text { TTT } \\
\mathrm{F}\end{array}$ & & 114-127 \\
\hline 6 & 51 & & & $\begin{array}{l}\text { GCT } \\
\text { A }\end{array}$ & $\begin{array}{l}\text { GAT } \\
\text { D }\end{array}$ & $\begin{array}{c}\text { TAA } \\
\text { b }\end{array}$ & $\ldots$ & & & & & 158-173 \\
\hline
\end{tabular}

Nucleotide sequences are in lowercase in introns and uppercase in exons.

The size of coding sequence.

${ }^{\mathrm{b}}$ Represents stop codons.

\section{Intraperitoneal glucose stimulation}

Twenty weeks old mice were fasted for $16 \mathrm{~h}$, and then glucose was injected intraperitoneally with $2 \mathrm{~g} / \mathrm{kg}$ body weight. Pancreases were isolated for protein extraction at $0,30,60$, and $90 \mathrm{~min}$ after glucose injection as previously described (Saeki et al. 2002). The purified islets also were cultured overnight in RPMI-1640 medium supplemented with $5.5 \mathrm{mmol} / 1$ glucose, $100 \mathrm{units} / \mathrm{ml}$ benzylpenicillin, $100 \mu \mathrm{g} / \mathrm{ml}$ streptomycin, and $10 \%$ fetal bovine serum before glucose stimulation tests. Fifty islets then were incubated in media containing $3.3 \mathrm{mM}$ or
$25 \mathrm{mM}$ glucose for $90 \mathrm{~min}$. Cells were harvested for measuring RESP18 protein by western blots.

\section{Results}

RESP18 is evolutionarily related to $I A-2$

Using a human pancreas cDNA library, two isoforms of human RESP18 were isolated by PCR amplification. RESP18 $\alpha$ encodes a protein 173 amino acids in length 
Table 2 Chromosomal localization and degree of relatedness to human RESP18

\begin{tabular}{|c|c|c|c|c|c|c|}
\hline & $\begin{array}{l}\text { RESP18 } \\
\text { isoform }\end{array}$ & $\begin{array}{l}\text { Chrom. } \\
\text { locus }\end{array}$ & $\begin{array}{l}\text { Amino } \\
\text { acid } \\
\text { residues }\end{array}$ & $\begin{array}{l}\text { Mass } \\
(\mathrm{kDa})\end{array}$ & $\begin{array}{l}\text { Identity/ } \\
\text { similarity } \\
(\% / \%)\end{array}$ & $\begin{array}{l}\text { Genbank } \\
\text { accession } \\
\text { number }\end{array}$ \\
\hline \multicolumn{7}{|l|}{ Species } \\
\hline \multirow[t]{2}{*}{ Human } & RESP1 $8 \alpha$ & $2 q 35$ & 173 & $19 \cdot 0$ & $100 / 100$ & AAQ04549a \\
\hline & RESP1 $8 \beta$ & $2 q 35$ & 228 & $24 \cdot 9$ & $90 \cdot 6 / 91 \cdot 8$ & AAQ04480 \\
\hline Chimpanzee & RESP18 $\beta$ & $2 \mathrm{~b}$ & 222 & $24 \cdot 3$ & $89 \cdot 3 / 91 \cdot 2$ & XP_001147413 \\
\hline Monkey & RESP18 & 12 & 186 & $19 \cdot 9$ & $89 \cdot 3 / 90 \cdot 6$ & XP_001102673 \\
\hline Bovine & RESP1 $8 \alpha$ & 2 & 174 & $19 \cdot 5$ & $69 \cdot 4 / 74 \cdot 1$ & NP_001071365 \\
\hline Pig & RESP $18 \alpha$ & ND & 174 & $19 \cdot 0$ & $73 \cdot 5 / 76 \cdot 5$ & AJ $648676\left(\right.$ EST) ${ }^{a}$ \\
\hline Rabbit & RESP1 $8 \alpha$ & ND & 174 & $18 \cdot 9$ & $74 \cdot 1 / 77 \cdot 6$ & EB375750 (EST) \\
\hline Rat & RESP1 $8 \alpha$ & $9 q 33$ & 175 & $19 \cdot 5$ & $60 \cdot 8 / 64 \cdot 3$ & NP_062151 \\
\hline Mouse & RESP1 $18 \alpha$ & 1 & 175 & $19 \cdot 5$ & $61 \cdot 4 / 65 \cdot 5$ & NP_033075 \\
\hline
\end{tabular}

$\mathrm{ND}$, not determined.

aDetermined in this study.

(Fig. 1A) and consists of six exons (exon 1c, 2, 3, 4, 5, and 7; Fig. 1B). At the protein level, RESP18 $\alpha$ shares 42 out of $46 \%$ identity/similarity with the luminal domain (aa 1-200) of IA-2, but only 28 out of $34 \%$ with that of IA- $2 \beta$. RESP18 $\beta$ encodes a protein 228 amino acids in length, consists of seven exons (exon 1a, 1b, 2, 3, 5, 6, and 7; Fig. 1B) and shares 41 out of $46 \%$ identity/similarity with IA-2. RESP18 $\beta$ shares $90 \cdot 0$ out of $91 \cdot 2 \%$ identity/ similarity to RESP $18 \alpha$, but the $\mathrm{N}$-terminal 42 amino acids and the C-terminal 29 amino acids of RESP18 $\beta$ are totally different from RESP18 $\alpha$ and show no significant similarity to other known domains. The detailed intronexon boundaries of RESP18 are summarized in the Table 1.

Further, analysis revealed that RESP18 and IA-2 are linked to the same sequence-tagged-site marker SHGC-32022 on 2q35 by Radiation Hybrid chromosome mapping panel and that RESP18 is localized just $18 \mathrm{~kb}$ upstream of the IA-2 transcriptional start site (Fig. 1B). The RESP18 genomic structure is similar to that of IA-2 in the region of the signal peptide (amino acids 1-34) and the following 77 amino acids (Fig. 1A and C). However, RESP18 lacks the sequence corresponding to exon 2 of IA-2, which encodes the IA-2 specific cysteine-rich region between aa 40-62 (Fig. 1A and C). We also found a homolog of RESP18 only $15 \mathrm{~kb}$ upstream of RESP18 (Fig. 1B). The fact that this homolog lacks an open reading frame (Table 1), commonly seen in recent duplicate events in evolution, suggests that this homolog is a pseudo gene. A search of gene databases revealed that RESP18 is found only in mammals (i.e. humans, chimpanzees, bovine, monkeys, pigs, rats, and mice) and not in invertebrates, making RESP18 different than IA-2, which is found in C. elegans and Drosophila (Cai et al. 2001a). Both the chromosomal localization and the degree of relatedness of RESP18 and IA-2 to each other in different species are shown in Fig. 1D and Table 2.
RESP18 is expressed in pancreatic islets and insulinoma cells

Northern blot analysis of several human tissues probed with RESP18 cDNA revealed a strong $0.8 \mathrm{~kb}$ band in the pancreas and two very weak bands at $0.8 \mathrm{~kb}$ and $1.2 \mathrm{~kb}$ in placenta respectively (Fig. 2A). A ${ }^{32} \mathrm{P}$-labeled $\beta$-actin probe used as a control showed equal mRNA levels in each lane (not shown). Western blot analysis using RESP18/JH1162 antibody (Fig. 2B) showed a $24 \mathrm{kDa}$ band in mouse pancreas, and a strong 18 out of $20 \mathrm{kDa}$ doublet in the INS-1 islet cell line and an $18 \mathrm{kDa}$ band in MIN6 and AtT-20 pituitary corticotropic cells. The higher molecular mass of RESP18 in pancreas $(24 \mathrm{kDa})$ might represent the RESP18 $\beta$ isoform or a post-translational modification of RESP18 $\alpha$. RESP18 expression was not found in non-neuroendocrine cells such as 3T3-L1, Hela, and HT29 cells. Similar amounts of total proteins loaded on each lane were confirmed by Coomassie blue staining (not shown).

Immunofluorescent staining of rat pancreas sections with antibody (JH1162) to rat RESP18 showed RESP18 in most islet cells examined (Fig. 2C-L). RESP18 was found in $\beta$ cells expressing insulin (Fig. 2D-F), $\alpha$ cells expressing glucagon (Fig. 2G-I), and $\delta$ cells expressing somatostatin (Fig. 2J-L). The fluorescent signal was somewhat stronger in cells near the periphery of the islets (Fig. 2C). A similar distribution was found at the human level. Figure 2M-O shows the co-localization of RESP18 and insulin in human $\beta$ cells using antibody (SVL421) to human RESP18.

\section{RESP18 is localized in dense core secretory vesicles}

Earlier studies with extracts of anterior pituitary showed by sucrose gradient analysis that RESP18 co-sedimented with the secretory vesicle markers (Darlington et al. 1997a). In the present study, the subcellular distribution of RESP18 was evaluated by immunoelectron microscopy with thin sections of rat pancreatic islets. Immunolabeling of pancreatic islet cells 

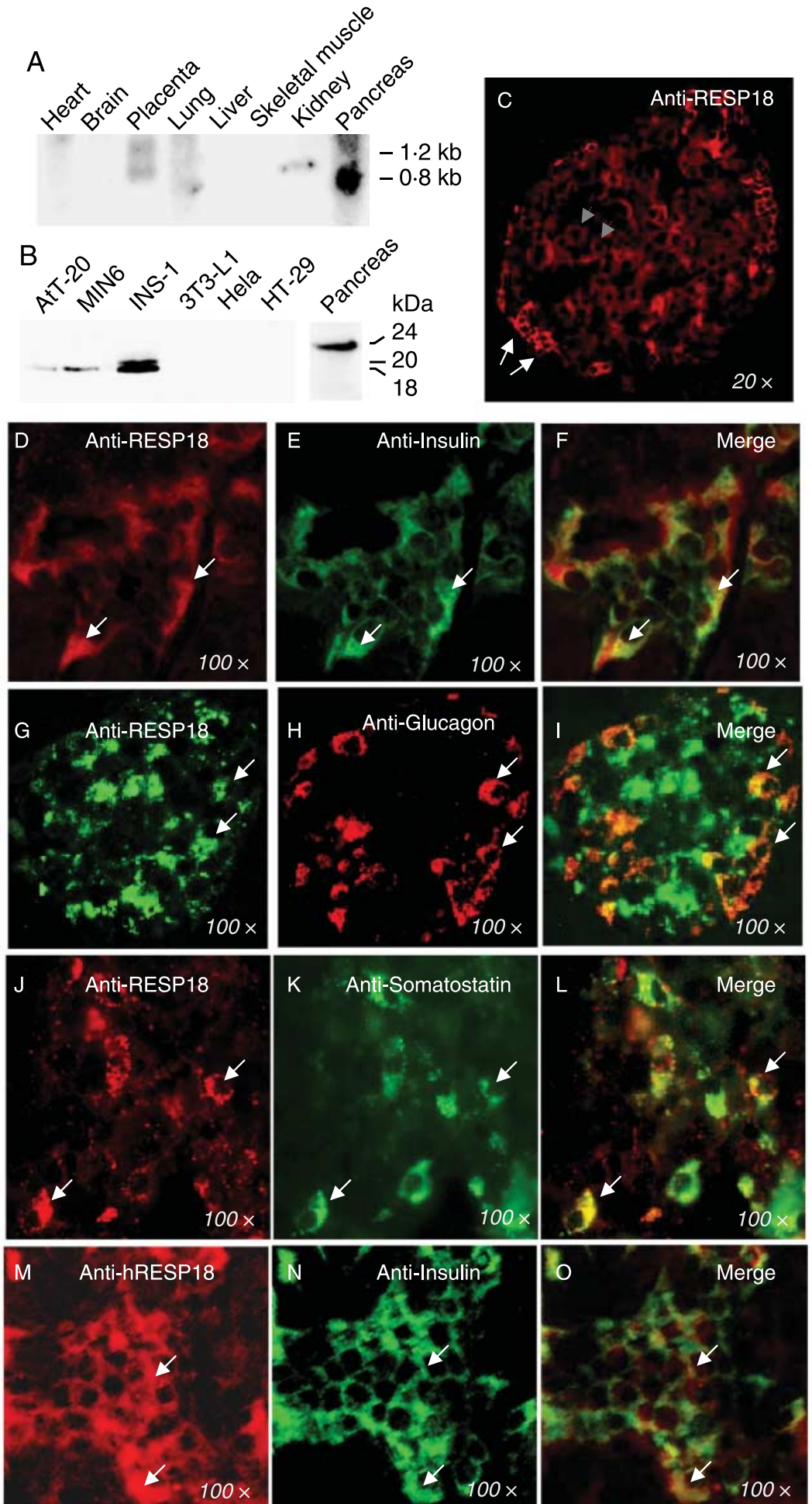

Figure 2 Expression of RESP18. (A) Northern blot analysis showing size and distribution of RESP18 transcripts in human adult tissues. (B) Western blot analysis showing size and distribution of RESP18 protein bands. (C) Most pancreatic islet cells react with anti-RESP18 antibody (JH1162) (in red). RESP18 level is higher in peripheral islet cells (arrows) than central islet cells (arrowheads in grey). RESP18 in $\beta$ cells $(\mathrm{D}-\mathrm{F}), \alpha$ cells $(\mathrm{G}-\mathrm{I})$ and in $\delta$ cells $(\mathrm{J}-\mathrm{L})$ as determined by double staining with antibodies to rat insulin, glucagon, and somatostatin. RESP18 in human $\beta$ cells as determined by antibody (SVL421) to human RESP18 (M-O). 

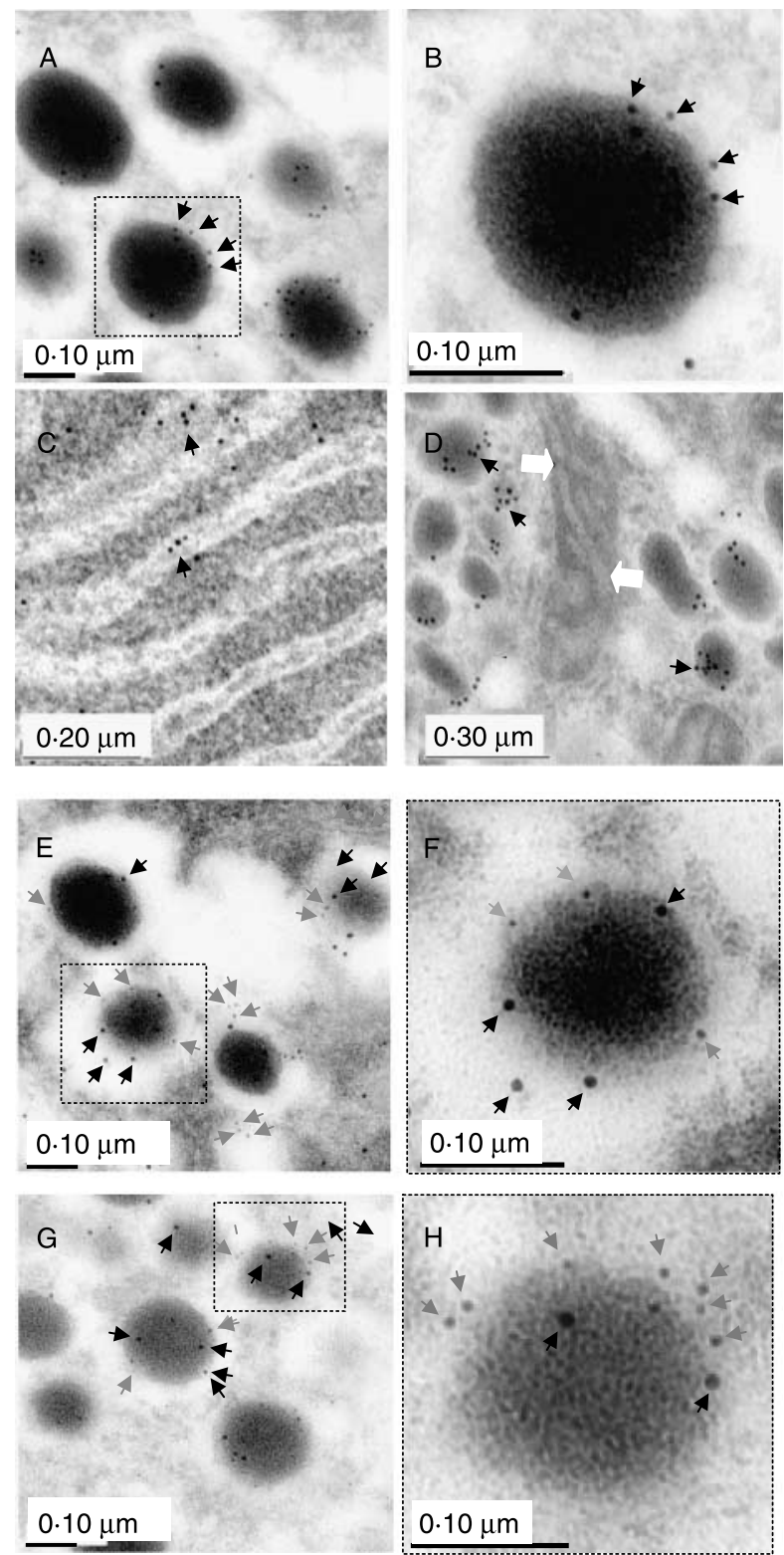

Figure 3 Subcellular distribution of RESP18. Rat pancreatic islets were fixed and used for immunoelectron microscopy as described in Materials and Methods. The binding of rabbit anti-RESP18 antibody (JH1162) to rat RESP18 was detected with goat anti-rabbit IgG antibody conjugated to $10 \mathrm{~nm}$ of colloidal gold. (A) RESP18 in DCVs as indicated by solid arrows and (B) amplified about threefold. (C) RESP18 (solid arrows) in endoplasmic reticulum. (D) RESP18 in DCVs (solid arrows) but not detected in mitochondria (open arrows). (E) RESP18 (detected by $5 \mathrm{~nm}$ of colloidal gold particles conjugated to goat anti-rabbit antibody, grey arrows) co-localizes with insulin in DCVs (10 nm colloidal gold particles conjugated to goat anti-mouse antibody, black arrows) in DCVs and (F) amplified about approximately threefold. (G) RESP18 (5 nm colloidal gold particles, grey arrows) co-localizes with glucagon (detected by $10 \mathrm{~nm}$ colloidal gold particles conjugated to goat anti-mouse antibody, black arrows) in DCVs and $(\mathrm{H})$ amplified about threefold. with antibody (JH1162) to rat RESP18 shows RESP18 in vesicles with typical dense cores (Fig. 3A and B). RESP18 also is present in ER and Golgi (Fig. 3C), but not in other intracellular structures such as mitochondria (Fig. 3D).

Co-localization of RESP18 with insulin in $\beta$ cells was demonstrated by double immunolabeling with rabbit antibody to rat RESP18 (5 nm colloidal gold particles conjugated to goat anti-rabbit antibody) and mouse antibody to insulin (10 nm of colloidal gold conjugated with goat antimouse antibody; Fig. 3E and F). Similarly, the co-localization of RESP18 ( $5 \mathrm{~nm}$ colloidal gold particles conjugated to goat anti-rabbit antibody) with glucagon in $\alpha$ cells was demonstrated with mouse antibody to glucagon $(10 \mathrm{~nm}$ colloidal gold particles conjugated to goat anti-mouse antibody; Fig. 3G and H). Quantization of RESP18 particles per square micrometer in 45 electron microscopic images revealed $94 \pm 47$ particles in DCVs when compared with $12 \pm 6$ particles in the cytoplasm (mean \pm s.D.; $P<0 \cdot 01$ ).

\section{RESP18 expression is upregulated by high glucose}

To evaluate the effect of high glucose on RESP18 transcription, mRNA levels were determined. Real-time PCR showed an approximately sixfold increase in RESP18 mRNA in MIN6 cells incubated with $25 \mathrm{mM}$ glucose for $90 \mathrm{~min}$, relative to cells incubated with $3.3 \mathrm{mM}$ glucose (Fig. 4A). Western blot analysis revealed nearly a ninefold increase in RESP18 protein in MIN6 cells exposed to high when compared with low glucose (Fig. 4B). The increase was detected within 15 min with peak levels being reached at 90 min (Fig. 4C).

In vivo, elevated glucose also increased RESP18 levels. Mouse pancreatic islets were isolated at different times after intraperitoneal injection of glucose $(2 \mathrm{~g} / \mathrm{kg}$ body weight; Fig. 4D). Western blots showed that RESP18 expression was increased at $60 \mathrm{~min}$, was highest at $90 \mathrm{~min}$ (Fig. 4D), and decreased thereafter (not shown). RESP18 protein also was increased in the islets of NOD mice following the development of diabetes. Western blots showed a tenfold increase at 2 days after the development of diabetes and a slightly lower increase at 10 days after the development of diabetes (Fig. 4E, lanes 2 and 3 respectively) when compared with RESP18 expression in non-diabetic NOD mice (Fig. 4E, lane 1).

\section{Discussion}

Our studies show that RESP18 is present in all mammals examined thus far. Monkey and chimpanzee RESP18 are about $90 \%$ identical to human RESP18, whereas mouse and rat RESP18 are only about 65\% identical to human RESP18. In addition, our studies have revealed two isoforms of RESP18 (RESP18 $\alpha$, RESP18 $\beta$ ) and a RESP18 pseudogene. These isoforms may explain some of the different molecular mass bands found in various tissues by western blots 


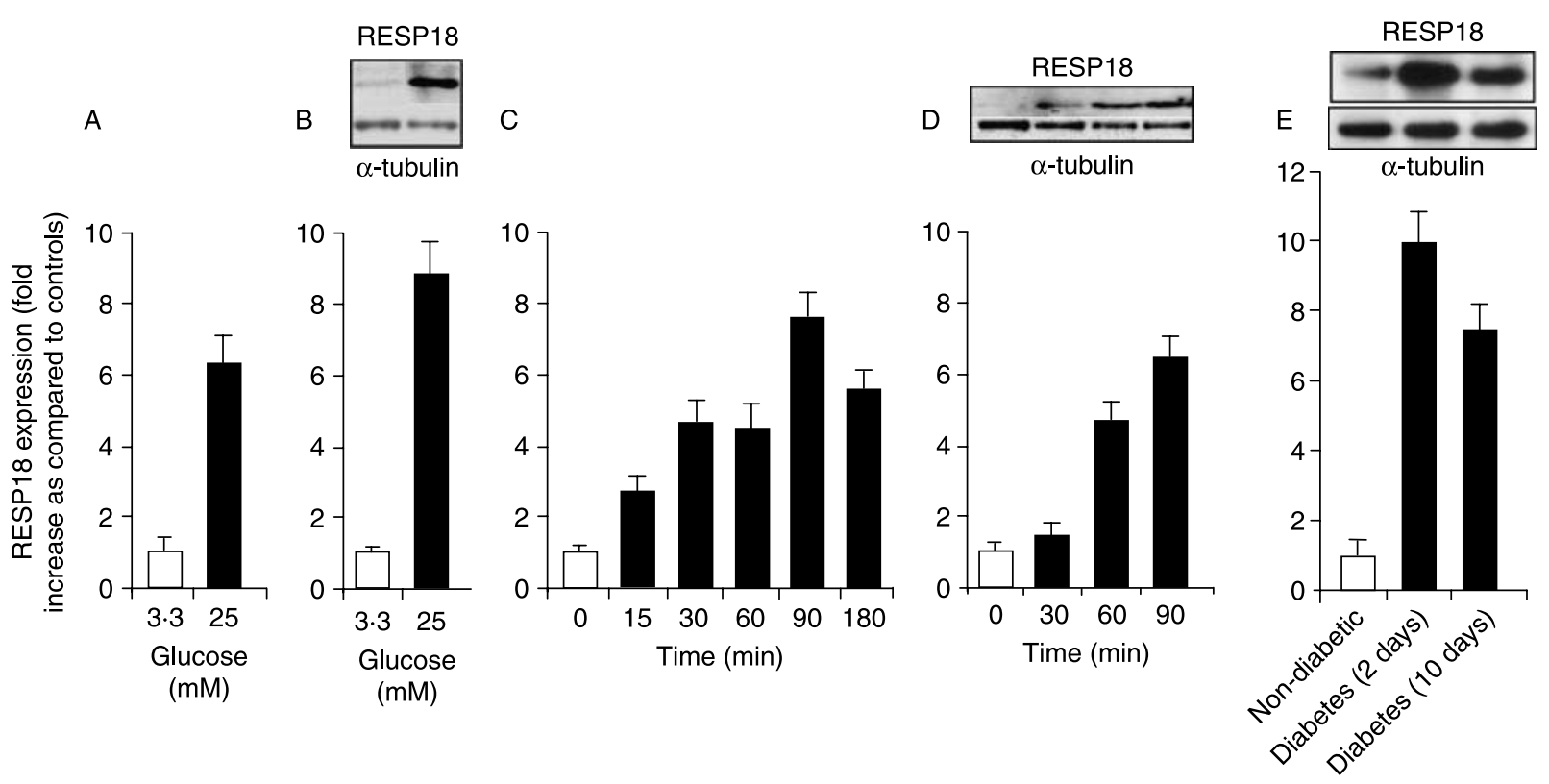

Figure 4 RESP18 expression upregulated by high glucose. (A) RESP18 mRNA as determined by real-time PCR following 90 min exposure of MIN6 cells to high $(25 \mathrm{mM})$ and low $(3 \cdot 3 \mathrm{mM})$ glucose. (B) RESP1 8 expression examined by western blotting of lysates of MIN6 cells that were incubated for $90 \mathrm{~min}$ with high $(25 \mathrm{mM})$ and low glucose $(3 \cdot 3 \mathrm{mM})$. (C) Time course of RESP1 8 expression examined by western blotting of lysates of MIN6 cells that were incubated with high $(25 \mathrm{mM})$ glucose. (D) RESP18 expression as determined by western blots of pancreatic lysates after intraperitoneal injection of glucose ( $2 \mathrm{~g} / \mathrm{kg}$ body weight). (E) RESP18 expression as determined by western blots in pancreas of non-diabetic and diabetic NOD mice (2 and 10 days after development of diabetes). Data from three separate experiments are presented as ratio of RESP18 to $\alpha$-tubulin (fold increase).

(Darlington et al. 1997a). RESP18 $\alpha$ and RESP18 $\beta$ are 173 and 228 amino acids in length respectively, and are encoded by alternative spliced exons. RESP $18 \alpha$ is $42 \%$ and RESP $18 \beta$ is $41 \%$ identical to a 200 amino acid stretch in the luminal domain of IA-2. Of particular interest, the genes that encode RESP18 and IA-2 are tandemly arranged within a small region of $<45 \mathrm{~kb}$ on human chromosome $2 \mathrm{q} 35$ and share a highly related genomic structure and sequence. RESP18 $\alpha / \beta$ is $18 \mathrm{~kb}$ upstream of IA-2 and RESP18-pseudo is $15 \mathrm{~kb}$ upstream of RESP18 $\alpha / \beta$. Taken together these findings suggest that RESP18 is evolutionarily related to IA- 2 and is a recently evolved member of the IA-2 family.

Initially RESP18 was thought to be expressed primarily in cells of the central nervous system (Darlington et al. 1996), but subsequent in situ hybridization studies revealed the presence of RESP18 in peripheral neuroendocrine cells including the islets of Langerhans (Darlington et al. 1997a). Our double immunofluorescence studies confirm and extend these findings and show RESP18 in insulinproducing $\beta$ cells, glucagon-producing $\alpha$ cells, and somatostatin-producing $\delta$ cells in the islets. In addition, by electron microscopy we show that RESP18 is located within the DCVs of these cells. However, the fact that IA2 contains a transmembrane domain and a cysteine-rich region (aa 40-62), whereas RESP18 does not contain either, argues that the function of these two proteins may be quite different.
Recent studies showed by knockout, knockdown and overexpression experiments that IA-2 can regulate the secretion of insulin and other hormones, presumably by stabilizing DCVs (Harashima et al. 2005). The region encoded by RESP18 that is homologous to IA-2 is located in the luminal domain of IA-2 for which no function, thus far, has been found. Eipper et al. (Bloomquist et al. 1994a, Darlington et al. 1997a) showed that RESP18 could be regulated by dopamine agonists and antagonists and reported finding RESP18 in the blood of rats, raising the possibility that RESP18 is a hormone. On the other hand, under physiologic conditions, Darlington et al. (1997a) were not able to demonstrate that RESP18 is secreted into cell culture media following stimulation with secretagogue. In the present study, we showed that stimulation of MIN6 $\beta$ cells with high glucose resulted in a five- to ten fold increase in both RESP18 transcripts and RESP18 proteins and that the increase occurred within 15 to $30 \mathrm{~min}$ after exposure to glucose. However, we too have not been able to demonstrate that either RESP18 or the luminal domain of IA-2 is secreted into the culture media following stimulation (Cai et al. unpublished data). Whether RESP18 or the luminal domain of IA-2 are intracellular luminal autocrine hormones, play a role in regulated secretory pathways, act as intracellular signaling molecules (Schiller et al. 1997) or have still other functions remains unknown. Nonetheless, the fact that RESP18 is evolutionarily conserved, is found in the DCVs of $\beta$ cells and can be increased five- to ten fold by exposure to high glucose 
makes it an interesting protein for further analysis in insulin and other neuroendocrine signaling pathways.

\section{Acknowledgements}

We thank Dr Michael Krause for comments and suggestions on this manuscript. We thank Charles Wohlenberg for technical help. This research was supported in part by the Intramural Research Program of the NIH, including ORS, NIDCR and NCI-Frederick. The authors declare that there is no conflict of interest that would prejudice the impartiality of this scientific work.

\section{References}

Bloomquist BT, Darlington DN, Mains RE \& Eipper BA 1994a RESP18, a novel endocrine secretory protein transcript, and four other transcripts are regulated in parallel with pro-opiomelanocortin in melanotropes. Journal of Biological Chemistry 269 9113-9122.

Bloomquist BT, Darlington DN, Mueller GP, Mains RE \& Eipper BA $1994 b$ Regulated endocrine-specific protein-18: a short-lived novel glucocorticoid-regulated endocrine protein. Endocrinology 135 2714-2722.

Cai T, Krause MW, Odenwald WF, Toyama R \& Notkins AL 2001 a The $I A-2$ gene family: homologs in Caenorhabditis elegans, Drosophila and zebrafish. Diabetologia 44 81-88.

Cai T, Xie J, She JX \& Notkins AL $2001 b$ Analysis of the coding and promoter regions of the autoantigen IA-2 in subjects with and without autoantibodies to IA-2. Diabetes 50 2406-2409.

Cai T, Fukushige T, Notkins AL \& Krause M 2004 Insulinoma-associated protein IA-2, a vesicle transmembrane protein, genetically interacts with UNC-31/CAPS and affects neurosecretion in Caenorhabditis elegans. Journal of Neuroscience 24 3115-3124.

Chen Y, Yu P, Lu D, Tagle DA \& Cai T 2001 A novel isoform of beta-spectrin II localizes to cerebellar Purkinje-cell bodies and interacts with neurofibromatosis type 2 gene product schwannomin. Journal of Molecular Neuroscience 17 59-70.

Darlington DN, Mains RE \& Eipper BA 1996 Location of neurons that express regulated endocrine-specific protein-18 in the rat diencephalon. Neuroscience 71 477-488.

Darlington DN, Schiller MR, Mains RE \& Eipper BA 1997 a The expression of regulated endocrine-specific protein of $18 \mathrm{kDa}$ in peptidergic cells of rat peripheral endocrine tissues and in blood. Journal of Endocrinology 155 329-341.

Darlington DN, Schiller MR, Mains RE \& Eipper BA $1997 b$ Expression of RESP18 in peptidergic and catecholaminergic neurons. Journal of Histochemistry and Cytochemistry 45 1265-1277.

Farkas RH, Qian J, Goldberg JL, Quigley HA \& Zack DJ 2004 Gene expression profiling of purified rat retinal ganglion cells. Investigative Ophthalmology \& Visual Science 45 2503-2513.

Goping G, Pollard HB, Srivastava M \& Leapman R 2003 Mapping protein expression in mouse pancreatic islets by immunolabeling and electron energy loss spectrum-imaging. Microscopy Research and Technique $\mathbf{6 1}$ $448-456$.
Harashima S, Clark A, Christie MR \& Notkins AL 2005 The dense core transmembrane vesicle protein IA-2 is a regulator of vesicle number and insulin secretion. PNAS 102 8704-8709.

Hermel JM, Dirkx R \& Solimena M 1999 Post-translational modifications of ICA512, a receptor tyrosine phosphatase-like protein of secretory granules. European Journal of Neuroscience 11 2609-2620.

Lan MS, Lu J, Goto Y \& Notkins AL 1994 Molecular cloning and identification of a receptor-type protein tyrosine phosphatase, IA-2, from human insulinoma. DNA and Cell Biology 13 505-514.

Lan MS, Wasserfall C, Maclaren NK \& Notkins AL 1996 IA-2, a transmembrane protein of the protein tyrosine phosphatase family, is a major autoantigen in insulin-dependent diabetes mellitus. PNAS 93 6367-6370.

Lu J, Li Q, Xie H, Chen ZJ, Borovitskaya AE, Maclaren NK, Notkins AL \& Lan MS 1996 Identification of a second transmembrane protein tyrosine phosphatase, IA-2beta, as an autoantigen in insulin-dependent diabetes mellitus: precursor of the $37-\mathrm{kDa}$ tryptic fragment. PNAS $\mathbf{9 3}$ 2307-2311.

Magistrelli G, Toma S \& Isacchi A 1996 Substitution of two variant residues in the protein tyrosine phosphatase-like PTP35/IA-2 sequence reconstitutes catalytic activity. Biochemical and Biophysical Research Communications 227 581-588.

Miyazaki J, Araki K, Yamato E, Ikegami H, Asano T, Shibasaki Y, Oka Y \& Yamamura K 1990 Establishment of a pancreatic beta cell line that retains glucose-inducible insulin secretion: special reference to expression of glucose transporter isoforms. Endocrinology 127 126-132.

Murray GJ \& Jin FS 1995 Immunoelectron microscopic localization of mannose-terminal glucocerebrosidase in lysosomes of rat liver Kupffer cells. Journal of Histochemistry and Cytochemistry 43 149-158.

Notkins AL 2002 Immunologic and genetic factors in type 1 diabetes. Journal of Biological Chemistry 277 43545-43548.

Ort T, Voronov S, Guo J, Zawalich K, Froehner SC, Zawalich W \& Solimena M 2001 Dephosphorylation of beta2-syntrophin and $\mathrm{Ca}^{2+} / \mathrm{mu}$-calpainmediated cleavage of ICA512 upon stimulation of insulin secretion. EMBO Journal 20 4013-4023.

Saeki K, Zhu M, Kubosaki A, Xie J, Lan MS \& Notkins AL 2002 Targeted disruption of the protein tyrosine phosphatase-like molecule IA-2 results in alterations in glucose tolerance tests and insulin secretion. Diabetes $\mathbf{5 1}$ 1842-1850.

Schiller MR \& Darlington DN 1996 Stage-specific expression of RESP18 in the testes. Journal of Histochemistry and Cytochemistry 44 1489-1496.

Schiller MR, Mains RE \& Eipper BA 1995 A neuroendocrine-specific protein localized to the endoplasmic reticulum by distal degradation. Journal of Biological Chemistry 270 26129-26138.

Schiller MR, Mains RE \& Eipper BA 1997 A novel neuroendocrine intracellular signaling pathway. Molecular Endocrinology 11 1846-1857.

Wasmeier C \& Hutton JC 1996 Molecular cloning of phogrin, a proteintyrosine phosphatase homologue localized to insulin secretory granule membranes. Journal of Biological Chemistry 271 18161-18170.

Received in final form 27 July 2007

Accepted 15 August 2007

Made available online as an Accepted Preprint 16 August 2007 